\title{
EXPLAINING ADOPTION OF CONSERVATION PROGRAMS BY LOCAL GOVERNMENTS
}

\author{
Ann O' M. Bowman and James L. Franke*
}

Introduction

On occasion, the incremental nature of local government policymaking will be upset by the intrusion of unavoidable events. Just such a situation arose in the $1970 \mathrm{~s}$ in the form of an energy crisis. Local governments across the nation were jolted into a new endeavor: energy management.

One of the major tools used in energy management is conservation (Stobaugh and Yergin, 1979). Conservation can be achieved through a number of means, most typically, the market price system and government intervention (Rosen, 1981). Government regulatory activity is commonly justified in terms of social benefits and often occurs when the market system is inefficient in producing the intended conservation effect. Government activity (or, more specifically, given the decentralized nature of energy conservation, local government activityl is the focus of this research. How has local government marshaled its legal, technical, and financial resources to pursue energy conservation? To answer this question, new empirical information from communities in an energy producing state (Texas) will be presented. ${ }^{1}$ Once the level and type of government activity has been determined, an analysis of potential explanations will be undertaken. Of interest is the underlying structure for what has been termed "the fitful and uneven involvement by local government in the energy field"' (Burt and Neiman, 1982).

\section{Measuring Community Conservation Activity}

As part of a national effort to decentralize energy conservation policy, local governments were expected not only to engage in energy conserving behaviors, but to proselytize as well. In the latter role, local governments were to de-

*Associate Professor of Government and International Studies, University of South Carolina and Assistant Professor of Political Science, Kansas State University. The authors wish to thank the anonymous reviewers for their insights. This research was partially funded from a grant provided by the Center for Energy and Mineral Resources, Texas A\&M University. velop strategies to market energy conservation to the community at large. In assembling these conservation programs, localities had an array of policy options from which to choose. The advantage of decentralization lay in the likelihood that local officials would design programs that fit within the context of local resources (Fitzsimmons, 1983). Therefore, in measuring conservation activity among Texas cities, differentiating among available programs according to the types of resources involved is crucial.

Table 1 indicates the adoption rates by Texas cities for a cross-section of local energy management options. ${ }^{2}$ The variety is clear. In terms of program focus, two categories emerge from the data. First, there are internal programs directly affecting the operations of city government (e.g., life-cycle costing, flexible working hours). Second, there are two types of externally oriented programs: (1) policies directed at the general public (e.g., information dissemination, ride-sharing); and (2) regulatory policies affecting commercial and developer groups (e.g., energy efficient building codes, reduction of ornamental lighting).

Adopting these programs constitutes an investment decision for local policymakers whose objective is to maximize benefits to the city government and not necessarily the community as a whole. As such, local officials will be concerned with securing a favorable return on their investment. The return may be figured in terms of an immediate payback or a deferred one. In its simplest form, their investment calculation involves weighing the costs of program implementation against anticipated benefits in either fiscal or political terms. Fiscal considerations tend to prevail when the adoption decision pertains to internal programs. The commitment of expenditures must be offset by the benefits realized through savings. The programs adopted are likely to result in a favorable rate of return because rational local governments will shun those which are negative. However, the size of the net gain will vary depending upon the ratio of the investment of fiscal resources to the reduction in 
Table 1

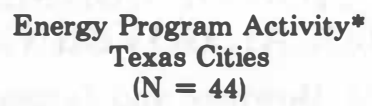

\begin{tabular}{|c|c|c|}
\hline Activity & & $\begin{array}{l}\% \text { of Cities } \\
\text { Reporting Activity }\end{array}$ \\
\hline PGM 1: & $\begin{array}{l}\text { Provide tax incentives to encourage private adoption of alternative } \\
\text { heating-cooling systems }\end{array}$ & 4.6 \\
\hline PGM 2: & Disseminate information concerning life-cycle costing & 4.6 \\
\hline PGM 3: & $\begin{array}{l}\text { Adopt building codes guiding solar and other alternative energy } \\
\text { applications }\end{array}$ & 13.6 \\
\hline PGM 4: & $\begin{array}{l}\text { Disseminate information concerning alternative and supplemental } \\
\text { energy sources }\end{array}$ & 13.6 \\
\hline PGM 5: & Discourage excessive ornamental lighting on private buildings & 15.9 \\
\hline PGM 6: & Disseminate information concerning recycling programs & 15.9 \\
\hline PGM 7: & Offer public employees the option of flexible working hours & 15.9 \\
\hline PGM 8: & Provide conservation loans & 20.5 \\
\hline PGM 9: & $\begin{array}{l}\text { Disseminate information concerning construction, lot orientation, } \\
\text { landscaping }\end{array}$ & 20.5 \\
\hline PGM 10: & $\begin{array}{l}\text { Establish energy budgets for each governmental department } \\
\text { or building }\end{array}$ & 22.7 \\
\hline PGM 11: & Pursue application of alternative energy for public buildings & 22.7 \\
\hline PGM 12: & $\begin{array}{l}\text { Encourage ride-sharing and the use of mass transit by public } \\
\text { employees }\end{array}$ & 22.7 \\
\hline PGM 13: & $\begin{array}{l}\text { Disseminate information concerning alternatives to private } \\
\text { vehicle use }\end{array}$ & 22.7 \\
\hline PGM 14: & $\begin{array}{l}\text { Require all new construction to meet nationally recommended } \\
\text { insulation and weatherization standards }\end{array}$ & 25.0 \\
\hline PGM 15: & Develop private ride-sharing or van-pooling programs & 25.0 \\
\hline PGM 16: & Revise zoning ordinances to allow multi-purpose or mixed land use & 25.0 \\
\hline PGM 17: & $\begin{array}{l}\text { Implement a comprehensive growth management plan which takes } \\
\text { energy conservation into account }\end{array}$ & 27.3 \\
\hline PGM 18: & $\begin{array}{l}\text { Disseminate information concerning building operation and } \\
\text { maintenance }\end{array}$ & 30.0 \\
\hline PGM 19: & $\begin{array}{l}\text { Encourage employees to use non-motorized means of } \\
\text { communication }\end{array}$ & 31.8 \\
\hline PGM 20: & Construct pedestrian walkways and bikeways & 34.1 \\
\hline PGM 21: & $\begin{array}{l}\text { Encourage utilities to provide residential and commercial } \\
\text { energy audits }\end{array}$ & 34.1 \\
\hline PGM 22: & $\begin{array}{l}\text { Evaluate electric rate structure changes which would promote } \\
\text { energy conservation }\end{array}$ & 36.4 \\
\hline PGM 23: & $\begin{array}{l}\text { Periodically revise building codes to incorporate conservation } \\
\text { techniques, materials, appliances, etc. }\end{array}$ & 40.9 \\
\hline PGM 24: & Consider adoption of alternative heating and cooling systems & 43.2 \\
\hline PGM 25: & $\begin{array}{l}\text { Disseminate information concerning residential and commercial } \\
\text { weatherization }\end{array}$ & 47.7 \\
\hline PGM 26: & Promote urban renovation for energy conservation benefits & 47.7 \\
\hline PGM 27: & Rehabilitate or weatherize existing public buildings & 47.7 \\
\hline PGM 28: & $\begin{array}{l}\text { Formulate contingency plan for public vehicles in case of fuel } \\
\text { curtailment }\end{array}$ & 54.6 \\
\hline PGM 29: & Relax employee dress code & 56.8 \\
\hline PGM 30: & Use life-cycle costing techniques & 56.8 \\
\hline PGM 31: & Develop energy-efficient routing for city vehicles & 59.1 \\
\hline PGM 32: & Promote private use of mass transit & 59.1 \\
\hline PGM 33: & Audit city energy usage by department or building & 61.4 \\
\hline PGM 34: & Increase public employee awareness of need for conservation & 77.3 \\
\hline PGM 35: & Maintain and operate city vehicles in an energy efficient manner & 79.6 \\
\hline PGM 36: & Observe FEA guidelines for thermostat settings & 93.2 \\
\hline
\end{tabular}


operating costs.

The adoption of external programs aimed at the general community or at commercial and developer elites will not translate into reduced operating costs for local government. The government will expend resources to implement and operate these programs, and will not experience any fiscal return. However, investment related benefits are not solely fiscal. "Prestige" benefits may be generated by program adoption. Prestige (or political) benefits refer to increased public support for the incumbent local administration as a result of its conservation related activities. Government intervention to produce the desired conservation effect is a matter for political calculus. In costbenefit terms, externally oriented programs normally need to be justified by political benefits. As with fiscal benefits, the size of the political gain will vary across different programs. Generally, the greater the scope of the audience positively affected by a program, that is, the wider the general welfare benefit, the greater is the associated political benefit.

It should be noted, however, that these political benefits may result from either policy activity or inactivity depending upon the structure of public opinion. There are, in effect, leadership incentives and disincentives connected with policy action (Ingram, et al., 1980). If the attentive public were generally concerned about the energy issue and also supportive of governmental policy leadership, incentives would exist for full scale conservation efforts. If, however, public sentiment were structured in the opposite manner, the political byproducts become added costs instead of counterbalancing benefits. This distinction is especially critical in energy producing states where there may not be a groundswell of public support for conservation (Riddlesperger, 1984).

Available public opinion data indicate that leadership incentives for community focused activity are not particularly strong (Cunningham and Lopreato, 1977). The public supports convenient, low cost energy conserving options (Weijo, et al., 1983), but clearly disfavors coercive conservation measures connected with municipal regulatory powers (Hamm, et al., 1978). This factor, coupled with the fiscal loss involved, may largely explain existing research findings that municipalities are taking little conservation action beyond internally oriented measures (Cigler, 1981).
With these considerations in mind, a typological indicator of municipal conservation activity has been developed.' One criterion for classification is the internal or external focus of the program. Consistent with the investment analogy, the second criterion reflected by this typology is the net return on investment for each of the programs. This involves an estimate of the fiscal commitment necessary to implement a basic program versus the anticipated reduction in city expenditures. A positive net return is generated by programs which, at low cost, produce a high yield. A negative return occurs when a high cost program produces inconsequential savings. Neutral returns can be generated in two ways: by low cost programs which produce only minimal savings and by programs which result in a high payoff but require a substantial financial allocation. In both instances, the net effect is neutral. Externally focused programs are complicated by the intrusion of a political calculus into the adoption decision. Costs and benefits are no longer confined to monetary transactions but include accretion and depletion of political capital. This suggests that city councilmembers may engage in programs with a seemingly negative return because of attendant political benefits. Thus for the councilmember, the net return is positive. This tendency can work in the opposite direction with councilmembers eschewing what appear to be positive return programs due to inherent political costs. Table 2 presents the program categorization based on fiscal return as well as the mean activity levels by program type for Texas cities.

Of the six available cells, only four have programmatic relevance. Internal conservation activities are likely to be of two varieties: those that produce neutral or positive net returns. Cities will avoid a resource commitment when the return is problematic, hence, the empty cell in the negative return category. This behavior conforms to expected patterns. External conservation activities reveal a different pattern. One would anticipate governmental involvement in low cost information dissemination activities because they represent financially harmless endeavors. Therefore, these programs are categorized in the typology as representative of a neutral return to the city government. Another cluster of programs produces negative returns. These are the costly 
Table 2

Fiscally Based Program Typology*

\begin{tabular}{|c|c|c|c|}
\hline \multirow{4}{*}{$\begin{array}{l}\text { NET } \\
\text { RETURN } \\
\text { ON } \\
\text { CITY'S } \\
\text { INVESTMENT }\end{array}$} & & ___ Internal & External \\
\hline & Positive & $\begin{array}{l}\text { mean activity } \\
\text { level = 55.5 } \\
\text { PGM10, PGM11, PGM27, PGM30, } \\
\text { PGM31, PGM33, PGM35, PGM36 }\end{array}$ & \\
\hline & Neutral & $\begin{array}{l}\text { mean activity } \\
\text { level = 43.2 } \\
\text { PGM7, PGM12, PGM19, } \\
\text { PGM24, PGM28, PGM29, } \\
\text { PGM34 }\end{array}$ & $\begin{array}{l}\text { mean activity } \\
\text { level = 28.3 } \\
\text { PGM2, PGM3, PGM4, PGM5, } \\
\text { PGM6, PGM9, PGM13, } \\
\text { PGM14, PGM16, PGM18, } \\
\text { PGM21, PGM22, PGM23, } \\
\text { PGM25, PGM26, PGM32 }\end{array}$ \\
\hline & Negative & & $\begin{array}{l}\text { mean activity } \\
\text { level = 22.3 } \\
\text { PGM1, PGM8, PGM15, } \\
\text { PGM17, PGM20 }\end{array}$ \\
\hline
\end{tabular}

* See Table 1 for specific program options.

items that return nothing to the city government in terms of energy savings. There are no external energy conservation programs with the potential to produce positive financial benefits, hence another empty cell.

The mean activity levels presented in Table 2 show that, as earlier work has noted (Cigler, 1981), internally focused programs have the highest adoption rates. ${ }^{4}$ Yet surprisingly, city efforts are not confined to symbolic measures or quick fixes, those falling into the neutral return cell. Texas cities are adopting programs that have a behavioral component, that is, they require action on the part of the city. The popularity of these programs can be traced to their potentially high return. While the implementation of the program may be of considerable cost to the city, the projected savings generated by the program render it a positive exchange. In other words, the benefits (the reduction in city energy-related expenditures) outweigh the costs of launching and operating the program. Weatherizing existing public buildings is just such a program.

The more problematic aspect of the typology relates to the external programs. Overall, they experience low adoption rates. This is not surprising because elected officials have an incentive to replace community welfare maximization with political welfare maximization. In an economy in which energy production is directly linked to prosperity, support for conservation is likely to be muted. The middle cell labeled neutral return contains programs which have a relatively negligible drain on the city's treasury. The majority of them are of the "disseminate information" variety. Yet these programs put the city into an advocacy role and this in itself has political ramifications. Other programs in this cell involve a potential political risk, that is, they are likely to capture the attention (and generate the opposition) of significant segments of the city. For example, adopting new building standards or revising zoning ordinances to secure reductions in energy usage affects the city's constructiondevelopment sector. That group is typically well placed in city politics, and can be influential in determining the outcome of relevant city policy (Fainstein, 1983). Depending on the direction of local public opinion, adoption (or non adoption) of this set of programs produces a non-neutral political reaction. What characterizes the external programs in the bottom cell is the fiscal commitment involved in implementation. Programs in this negative return category represent an action response accompanied by a high price tag. The low adoption rate sugests that few elected officials perceive that these programs possess political utility. These programs are then, doubly doomed. Their adoption does not produce a direct financial benefit to city government and they may generate unpalatable political consequences. 


\section{Community Resources}

The typology clusters energy conservation programs into four rough groupings. To understand what is affecting government behavior, a different sort of analysis is necessary. If, in fact, municipal conservation activity is a multifaceted phenomenon, then one would expect the different program types to be sensitive to the presence or absence of different aggregate fiscal and political resources in these communities.

The influence of three fiscal factors will be evaluated: community wealth, city size, and professional staff. Conventionally, it is assumed that these factors reflect different varieties of organizational slack. Where slack is present, it is argued that there will be greater latitude for programmatic innovation (Cyert and March, 1963; McGowan and Stevens, 1983). Hence, wealth, size and staff are quite frequently portrayed as interchangeable indicators of the same phenomenon.

The theoretical rationale offered for the policy relevance of wealth centers around the costly nature of new programs. This assumes, however, that most new programs are expensive and this may not hold for local energy conservation policy. It seems more reasonable to view community wealth as a potential resource which may be tapped should a specific need arise. That is, wealth is more likely to be related to the adoption of expensive innovations. The most expensive types of conservation programs are those involving a substantial monetary investment and which are directed at the general community (external, negative return). Hence, one would expect community wealth to be correlated with these types of activities.

The relationship between wealth and innovation, however, presupposes that community wealth translates into governmental wealth. This supposition may be faulty. Consequently, two measures of affluence will be included in the subsequent analysis. Community wealth will be measured by per capita income and governmental wealth by per capita municipal expenditures.

The importance of city population size for the adoption of new programs is explained substantially in the same terms as wealth. An additional argument often made on behalf of size is that it increases the likelihood of scalar economies. However, others argue that community size is more accurately conceptualized as a "conglomerate" variable which may or may not tap the same phenomenon as wealth (Downs, 1976). That is, phenomena accompanying size rather than size itself are the relevant explanatory factors. Of importance here is the suggestion that size is linked to policy outputs through municipal staff resources.

There are several explanations offered for the policy relevant impact of staff size. First, larger cities tend to serve as leaders in policy adoption and their professionalized staffs provide readily available, reasonably well-trained personnel for program implementation. Second, this leadership role suggests that larger municipal bureaucracies are more likely to be aware of novel programmatic approaches (Anderson, 1983). Both city size and professional staff should be especially strong predictors when the return on the city's investment is the most marginal. ${ }^{6}$

Public support is, theoretically, a primary factor underlying governmental action. While unable to gauge citizen opinion directly, data from the survey of city councilmembers will serve as a surrogate measure. Specifically, the council members were asked to indicate their level of support, in principle, for each of twelve different conservation programs. ${ }^{\circ}$ Each respondent was given a score based upon a summation of the individual evaluations. Aggregate city council scores were then calculated by taking the mean of individual scores. Only those councils from which a majority of the members responded will be included in the subsequent analysis.

One would expect the measure of political support to be associated with both categories of externally focused programs. Substantial political benefits would seem necessary to offset negative net return conservation programs and at least minimal public support would be required to implement neutral return programs.

The dependent variables in the analysis are the four program categories. A more conventional unidimensional indicator of program activity-a measure of "overall activity"-is also used. This indicator represents the proportion of all programs, regardless of type, in which communities are active. Consistent with the argument that some programs will be responsive to fiscal resources and others to political resources, one would expect the 
Table 3

Independent Variables: Product Moment Correlations ( $r$ )

$(\mathrm{N}=41)$

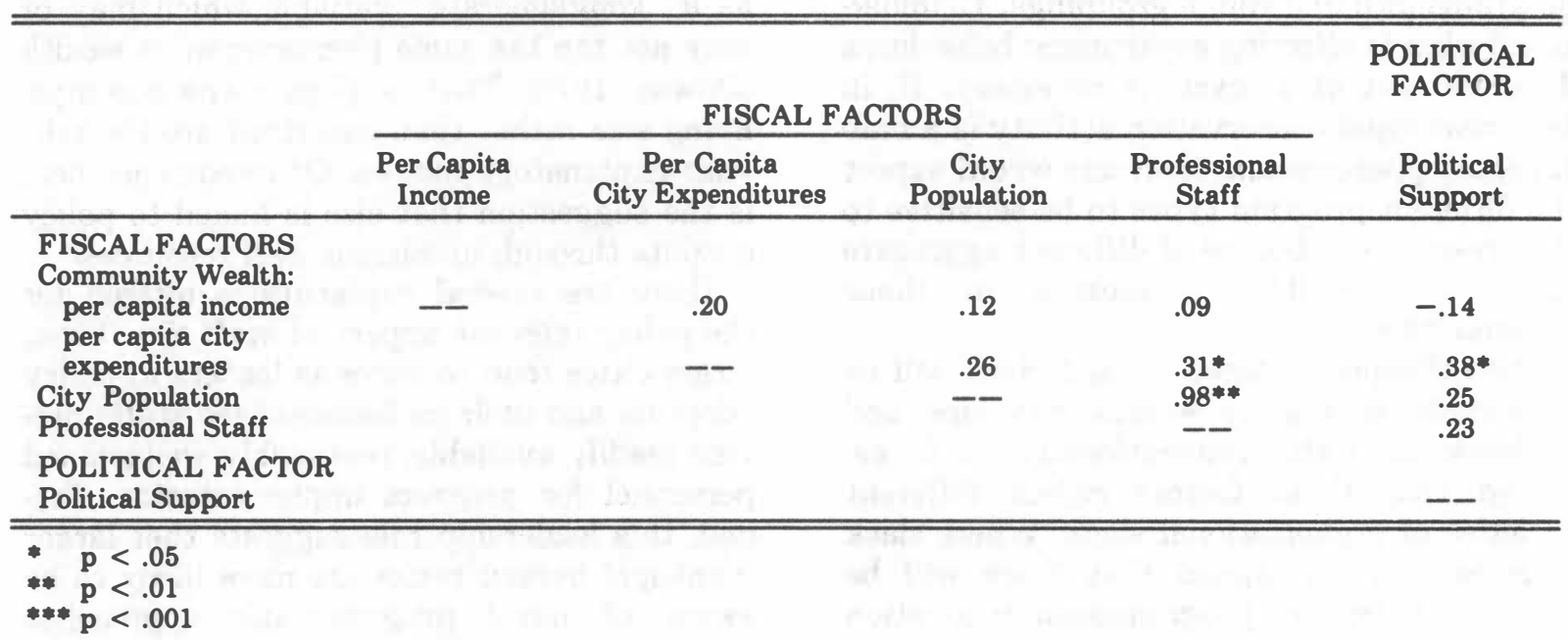

unidimensional indicator to be sensitive to both. Specifically, overall activity should be associated with political support, population, and staff size. However, given the prediction that community wealth should only come into play with a few of the conservation programs, it seems unlikely that it would be significantly related to the measure of general activity.

\section{Analysis}

Table 3 presents the intercorrelations among the predictor variables. Two observations are noteworthy. First, in these data, two indicators, community population and staff size, are virtually colinear. Second, community wealth
- per capita income-is not a component of the general phenomenon reflected by the other four variables. Political support, population, expenditures, and employees are all interrelated at low to moderate levels. Community income, however, is unrelated to the other measures of fiscal and political resources. In Texas, wealthier communities are not necessarily the large cities and community wealth does not translate into governmental wealth as measured by per capita expenditures.

The correlations between each of the predictor variables and the different measures of conservation activity are presented in Table 4 . The influence of the two indicators of wealth once again underscores the basic disjuncture be

Table 4

Independent Variables and Conservation Programming: Product Moment Correlations (r) $(\mathrm{N}=41)$

\begin{tabular}{|c|c|c|c|c|c|}
\hline & $\begin{array}{l}\text { General } \\
\text { Activity }\end{array}$ & $\begin{array}{l}\text { Internal } \\
\text { Positive } \\
\text { Return }\end{array}$ & $\begin{array}{l}\text { Internal/ } \\
\text { Neutral } \\
\text { Return }\end{array}$ & $\begin{array}{l}\text { External/ } \\
\text { Neutral } \\
\text { Return }\end{array}$ & $\begin{array}{c}\text { External/ } \\
\text { Negative } \\
\text { Return }\end{array}$ \\
\hline $\begin{array}{l}\text { FISCAL FACTORS } \\
\text { Community Wealth: } \\
\text { per capita income } \\
\text { per capital city }\end{array}$ & .09 & .17 & .08 & .20 & -.19 \\
\hline $\begin{array}{l}\text { expenditures } \\
\text { City Population } \\
\text { Professional Staff }\end{array}$ & $\begin{array}{l}.16 \\
.35^{*} \\
.42^{* *}\end{array}$ & $\begin{array}{r}-.18 \\
.11 \\
.17\end{array}$ & $\begin{array}{l}.25 \\
.28^{*} \\
.31^{*}\end{array}$ & $\begin{array}{l}.15 \\
.48^{* * *} \\
.51^{* * *}\end{array}$ & $\begin{array}{l}.38^{* *} \\
.37^{* *} \\
.45^{* *}\end{array}$ \\
\hline $\begin{array}{l}\text { POLITICAL FACTOR } \\
\text { Policial Support }\end{array}$ & $.27 *$ & .01 & $.30^{* *}$ & .25 & $.31 *$ \\
\hline
\end{tabular}


tween community and governmental affluence. Per capita income has no policy relevant impact. Even in the case of negative return programs benefiting the community at-large, where the potential of local affluence might be tapped, community wealth is of no consequence. Governmental wealth-per capita expenditures-is not associated with overall rates of conservation activity. However, as expected, it is instrumental in the adoption of externally oriented, negative return programs.

Likewise, the indicator of political support for conservation programming conforms to our expectations. It is important to overall rates of activity. Most importantly, the push of politics is felt in those program areas that benefit the citizenry generally.

The phenomena tapped by staff size are the most salient features of the policy process leading to the adoption of municipal conservation programs. Professional staff are apparently closely associated with aggressive energy management. As predicted, this is especially the case when the return is other than positive. Large city staffs are also linked to activities which maximize community welfare.

These results are encouraging vis-a-vis the theoretical implications of the typology. Once again, the predictions suggested are for the most part realized. Programs with a negative return directed at the community require both fiscal and political resources. Others which are neutral, whether internally or externally oriented, are sensitive to fiscal resources as represented by staff capabilities. Internal programs with a neutral return are linked to political support as well. Finally, those programs which are internally oriented and produce a high net return appear to be unrelated to the fiscal and political factors tested here. It is these highly attractive energy management measures which most Texas communities are adopting.

\section{Conclusion}

Local conservation policy is influenced by citizen support and the resources made available by larger, more professional city staffs. ${ }^{8}$ It appears that staff initiative is generally accentuated in this policy area due to the neutral return of many energy management activities. In larger cities especially, the professional nature of bureaucracies seems to result in a greater awareness of these state of the art techniques for reducing energy consumption. More than likely, innovations diffuse through professional channels and are picked up by city staff members in larger communities.

Texas communities prefer internally oriented programs at the expense of external activities designed to alter citizen energy consumption habits. Similar results have led others to question the sincerity of the efforts being made by local governments to confront the energy issue and hence contribute to a national conservation program (Cigler, 1982). As a result, gloomy predictions for the decentralized future have followed as a matter of course. However, it seems somewhat premature to conclude that local conservation efforts are dying a slow, but inexorable, death.

Energy costs are a major chunk of local governments' budgets. Cities appear to be behaving in an efficient manner by concentrating their energy conservation efforts in activities that yield immediate cost savings. Local decision makers are pursuing the path of least resistance. This may not imply innovative leadership, but it does suggest political rationality.

\section{FOOTNOTES}

'The data were collected during the summer of 1980 through a mail survey directed to the mayors or city managers of the 52 largest communities-population 25,000 and above-in Texas. The instrument consisted of an inventory-like checklist of different energy conservation initiatives. Through repeated mail and telephone attempts, we were able to obtain responses from 85 percent, or 44 of our target communities. Responding to the questionnaire were 18 of the 23 cities with 1975 populations of $25,000-49,999 ; 14$ of the 16 cities with populations of $50,000-99,999 ; 9$ of the 10 cities with populations of 100,000-499,999; and all three of the cities with 1975 populations in excess of 499,999 .

'These specific programmatic options were chosen following an extensive review of the existing technical, governmental, and scholarly literature dealing with both the options currently available as well as those most commonly used. See, for example, The Conference on Alternative State and Local Policies (1980) Local Alternative Energy Futures, Washington, D.C.: CASLP and U.S. Department of Housing and Urban Development (1979) Compendium of Federal Programs Related to Energy Conservation, Washington, D.C.: HUD. In developing the inventory the objective was to be as eclectic and comprehensive as possible. A city was awarded a " 1 " for each program it had adopted, and a " 0 " for each program in which it was not participating.

'The typology was derived from responses to the survey noted above and from a subsequent survey conducted through the mail in the spring of 1981. The focus of the second survey was upon the councilmembers in the state's 
52 largest cities-populations of 25,000 and over. Three hundred sixty-one officials were contacted; 184 , or 51 percent, returned usable questionnaires. An examination of the distribution of responses in terms of the cities represented revealed no bias.

"In Table 2, the activity rates presented reflect means across all cities of the proportion of programs in each category in which each city reported activity. In the subsequent analysis, the dependent variables will thus be the four proportions for each community.

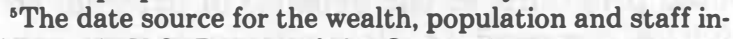
dicators is U.S. Bureau of the Census (1978).

${ }^{6}$ The programs to which the councilmembers reacted reflect a mixture of the four program types delineated in the typology. Respondents were asked to indicate their level of support for the following energy management programs on a five point scale: 1) reduce street lighting levels; 2) disseminate information concerning weatherization; 3) develop ride-sharing or van-pooling programs; 4) pursue application of alternative energy for public buildings; 5) encourage ride-sharing or the use of mass transit by public employees; 6) rehabilitate or weatherize existing public buildings; 7) promote urban redevelopment; 8) construct or improve pedestrian walkways and bikeways; 9) observe FEA guidelines for thermostat settings; 10) revise city zoning ordinances to allow multi-purpose or mixed land use; 11) discourage excessive ornamental lighting on private buildings; 12) provide or facilitate conservation loans.

${ }^{7}$ Admittedly the opinions expressed by these public officials might well diverge somewhat from the results of an actual citizen survey. Public opinion research has demonstrated as much. That same research, however, has also shown that the preferences expressed by elected officials are quite often representative of the opinions of politically active citizens. We assume that phenomenon to be operative in these data.

${ }^{8}$ Multivariate analysis with a larger sample of cities would be helpful in validating the strength of this finding.

\section{REFERENCES}

Anderson, Wayne F. The Effective Local Government Manager. Washington, D.C.: International City Management Association, 1983.

Burt, Barbara J. and Max Neiman. "Citizen Receptivity to Energy Policy Innovation." Paper presented at the
Annual Meeting of the Western Political Science Association, San Diego, March 26, 1982.

Cigler, Beverly A. "Intergovernmental Roles in Local Energy Conservation: A Research Frontier." Policy Studies Review 1: 761-776, 1982.

"Organizing for Local Energy

Management: Early Lessons." Public Administration Review 41: 470-479, 1981.

Cunningham, William H. and Sally Cook Lopreato. Energy Use and Conservation Initiatives: $A$ Study of the Southwestern United States. New York: Praeger, 1977.

Cyert, Richard M. and James G. March. A Behavioral Theory of the Firm. Englewood Cliffs, NJ: PrenticeHall, 1963.

Downs, George W., Jr. Bureaucracy, Innovation, and Public Policy. Lexington, MA: D. C. Heath, 1976.

Fainstein, Susan S., et al. Restructuring the City. New York: Longman, 1983.

Fitzsimmons, Allan. "State Energy Policymaking." Natural Resources Journal 23: 305-322, 1983.

Hamm, Keith E., Ronald D. Hedlund, and Robert M. Stein. "Attitudes Toward Energy Conservation: Acceptance of Coercive Government Policies." Paper presented at the Annual Meeting of the Southwestern Political Science Association, Houston, TX, April 12-15, 1978.

Ingram, Helen, Nancy Laney and John R. McCain. A Policy Approach to Political Representation: Lessons from the Four Corner States. Baltimore, MD: Johns Hopkins University Press, 1980.

McGowan, Robert P. and John M. Stevens. "Local Government Initiatives in a Time of Uncertainty." Public Administration Review 43: 127-136, 1983.

Riddlesperger, James W. "Institutional Capability and Energy Policy Development in the American States." Paper presented at the Annual Meeting of the Southwestern Political Science Association, Ft. Worth, TX, March 21-24, 1984.

Rosen, David J. "Local Energy Options and National Policy: A Changing Environment." The Urban Interest 3: 57-65, 1981 .

Stobaugh, Robert and Daniel Yergin (eds). Energy Future. New York: Random House, 1979.

U.S. Bureau of the Census. Statistical Abstract of the United States. Washington, D.C.: Government Printing Office, 1978.

Weijo, Richard, Gary Dodge, and William Rudelius. "Stimulating Energy Conservation by Homeowners: A Planning Model for Local Government." Public Administration Review 43: 433-443, 1983. 